\title{
STATUSNA PITANJA EKONOMSKIH IZBEGLICA I IZAZOVI ZA EVROPSKU UNIJU
}

\author{
STATUS ISSUES OF ECONOMIC REFUGEES AND \\ CHALLENGES FOR THE EUROPEAN UNION
}

\section{Vladimir Todorović}

Beogradska poslovna škola -Visoka škola strukovnih studija, Beograd, Srbija

\section{Miloš D. Lutovac}

Beogradska poslovna škola -Visoka škola strukovnih studija, Beograd, Srbija

\section{Jovana Radulović}

Beogradska poslovna škola-Visoka škola strukovnih studija, Beograd, Srbija

CMESTE

JEL Category: F22, 015, R23

\section{Apstrakt}

Regionalna neravnomernost izražena u ekonomskom stepenu razvijenosti pojedinih delova sveta predstavlja jedno od najkompleksnijih razvojnih problema. Evropa, a pogotovo države Evropske unije godinama su suočene sa velikim prilivom migracija, koje su prouzrokovane velikim regionalnim razlikama između razvijenih i nerazvijenih zemalja, a koje se, pre svega, odnose na snažnu depopulaciju, nepovoljnu demografsku strukturu, ekonomsku zaostalost nerazvijenih područja i nizak stepen infrastrukturne opremljenosti. Utvrđivanje stepena ekonomsko-geografske razvijenosti država, regiona, subregiona, okruga ili opština zahteva uporedno praćenje više uzajamnih pokazatelja. Proučavanje fenomena migracija ima dugu tradiciju i kontinuitet u okviru društvenih, prirodnih i humanističkih nauka. U ekstremnim okolnostima, kada su ljudi primorani da se isele u druge države, jer im je to jedini izlaz iz područja zahvaćenog ratnim dešavanjima, uglavnom se kvalifikuju kao raseljena lica. Analize istraživanja ovih pojava pokazuju da je vremenski horizont postojanja ekonomskih izbeglica i migracija, ekvivalent istoriji čovečanstva, a sadašnja demografska slika sveta jednim delom je rezultat njihovog postojanja. Upamćeni događaji međunarodnih migracija, koje su počele 2015 godine, a verovatno će potrajati u godinama koje slede, pokazuju na potencijal i moguće razvojne efekte ovih demografskih procesa. Ali, fokus međunarodnih pogleda na svet migranata brzo se menja, te oni od kreativnih činioca ekonomskog rasta i razvoja u državama odrednicama, postaju pretnja religijskoj, političkoj i socijalnoj stabilnosti blagostanja država njihovog odredišta.

Adresa autora:

Vladimir Todorović

莑vladimir.todorovic@bbs.edu.rs
Ključne reči: migracije, ekonomske izbeglice, demografija, rast i razvoj, politička stabilnost. 


\section{Abstract}

Regional variation reflected in the economic development level of certain parts of the world is one of the most complex development problems. Europe, and especially the countries of the European Union for years have been faced with a large influx of migrations, caused by large regional differences between developed and developing countries, and which are primarily related to the strong depopulation, unfavorable demographic structure, economic backwardness of underdeveloped areas and the low level of infrastructural equipment. Determining the degree of economic and geographical development of the countries, regions, sub-regions, districts or municipalities requires parallel monitoring of multiple mutual indicators. The study of the phenomenon of migration has a long tradition and continuity within social and natural sciences and humanities. In extreme circumstances, when people are forced to migrate to other countries because it is their only way out of the area affected by the war, they are mainly qualified as refugees. Research analysis of these phenomena shows that the time horizon of the existence of economic refugees and migrations is equivalent to the history of humanity, and the current demographic picture of the world is partly the result of their existence. The remembered events of international migration, which began in 2015, and is likely to continue in the years that follow, indicate the potential and possible developmental effects of these demographic processes. But the focus of international attitudes towards the world of migrants is changing rapidly, and therefore, from being a creative factor of economic growth and development in destination countries, they are becoming a threat to the religious, political and social stability of the welfare of their destination countries.

Keywords: migration, economic refugees, demography, growth and development, political stability.

\section{UVOD}

Prostorna kretanja stanovništva koja se posebno intenziviraju usled ubrzanog razvitka tržišta, boljeg saobraćaja, raznih vidova komunikacija i sve boljim informacionim tokovima, po mišljenju mnogih autora, jedna su od centralnih kategorija društvenih i socijalnih promena. (Albrecht, 1972). Shodno tome kretanja ljudi ulaze u središte interesovanja i proučavanja mnogih naučnih disciplina, pa su migracije neizostavne $u$ izučavanju kako mikro socijalnog tako i makro socijalnog razvoja celog čovečanstva. (Jonjić, 1984).

Istorija čovečanstva je neprekidno kretanje ljudi (migriranja i izbeglištva). Ove pojave su zapravo kontinuirani procesi stari koliko i čovečanstvo, te su zbog svog obima i značaja postale deo kolektivne svesti čovečanstva. Migracije su, iako promenljive jačine i obima, najčešće determinisane nekim od prirodnih, socijalnih ili ekonomskih uslova. Mnoge prirodne nepogode i krize u socijalnom preživljavanju i evoluciji ljudskih zajednica (promene klime, suše, poplave, zemljotresi, pandemije, ratovi i drugo) uslovile su nastanak mitova i predanja o kataklizmama fiksiranim u kosmogonijama, Bibliji i drugim svetskim knjigama. Ali, pravi razlog pojedinačnih i kumulativnih kretanja stanovništva veoma teško je odrediti (Jovanović Popović, 2015).
$\mathrm{U}$ proučavanju ovog problema neophodan je skladan odnos između čoveka i prostora, a srž tog odnosa jeste proces koji ne ostavlja samo trag ljudskog delovanja u prostoru, nego utiče na formiranje socijalnih struktura i ponašanja na određenim geografskim teritorijama, te svojim kretanjem i delovanjem daje sliku društvenosocijalnog i kulturnog razvitka (Tošić D., 2012). Često se proces kretanja stanovništva samo parcijalno proučava ili se opisuju samo njegove posledice (psihičke, socijalne, ekonomske, demografske, geografske, kulturne i druge) jer ga je teško obuhvatiti i proučiti u celosti. Dakle, tradicionalne teorije nisu postavljale pitanje, zašto se tokovi međunarodnih migracija nastavljaju $\mathrm{i}$ posle prestanka delovanja njihovih inicijalnih faktora (Predojević Despić, 2009).

U nastavku radu ukazaćemo na značaj proučavanja migracija u okviru migracionih sistema, kao osnove za razumevanje migracionih tokova, njihove veličine, smera kretanja te budućih demografskih dešavanja i statusnih pitanja ekonomskih izbeglica kao nametnutih izazova Evropskoj uniji.

Proučavanje kretanja stanovništva, bila ona dobrovoljna ili prisilna usled prirodnih neprilika ili ratova, odnosno istraživanje uticaja migracija stanovništva na prostorno-funkcionalnu organizaciju regionalnih celina različitih 
teritorijalnih i demografskih veličina, u geografiji, nemaju dugu istoriju. Kretanje stanovništva na relaciji selo-grad, grad-grad ili država-država, tj. migracije najčešće su istraživane sa demografskog aspekta uz primenu demografskih metoda kroz analizu broja i strukturu migranata, dok su faktori i uzroci njenog obima, smerova i vremena trajanja, stavljani u drugi plan (Jovanović Popović, 2015).

Ovakvo posmatranje migracija je prekinuto četrdesetih godina prošlog veka ulaskom socijalne geografije u funkcionalnu fazu razvoja, od kada se dnevna i svaka druga migracija izučava u sklopu kompleksa uzročno-posledičnih procesa proizašlih iz prostornih i funkcionalnih datih teritorijalnih celina u određenom vremenu. Od tada se kretanje stanovništva koristi kao indikator funkcionalne i regionalne diferencijacije prostora. Od pedesetih godina prošlog veka, kvantitativnokvalitativnim obeležjima o kretanju kako zaposlenih i korisnika kompleksa usluga sociekonomskog i kulturnog karaktera, tako i reseljenih lica usled nevolja, determinišu se polja uticaja centralnih naselja, tj. određuje se intenzitet i polja teritorijalnog dometa njihovih funkcija. Sedamdesetih godina dvadesetog veka, u vreme intenzivne kvantifikacije geografije i primene zakona socio fizike u geografskim istraživanjima, obim, intenzitet i smerovi migracije stanovništva objašnjavani su modifikovanim zakonom gravitacije po kome je broj migranata u drugi centar rada proporcionalan broju i kvalitetu u njemu koncentrisanih radnih mesta, a obrnuto proporcionalan udaljenošću centara stanovanja migranata (Tošić, Krunić, \& Petrić, 2007).

Sve vrste migracija usko su povezane sa hijerarhijom naselja, te činjenicom da uticajne sfere funkcija različitih naselja nemaju isti značaj $i$ domet. Udaljenost od glavnih urbanih centara jedan je od najvažnijih faktora uticaja na migraciju, odnosno područja u blizini ili sa većom dostupnošću gradovima daju većinu migranata datim gradovima. Akcenat je najčešće stavljan na radni centralitet određen uticajem funkcija centara rada na dnevnu pokretljivost stanovništva. $\mathrm{Na}$ osnovu ovoga, stepen međuzavisnosti stadijuma urbanizacije i prostorne pokretljivosti stanovništva možemo podeliti u tri modela (primarni, sekundarni i tercijalni) (Petersen, 1958), (Zelinsky, 1971). (Bolte, 1969), (Klingbeil, 1969), (Klingbeil, 1980). U sva tri pomenuta modela, a i u više kasnije razvijanih njihovih modaliteta, istaknuta je činjenica da vremensko trajanje, regionalni $i$ lokalni razmeštaj ishodišta i odredišta migracije stanovništva predstavlja faktor funkcijskog oblikovanja geoprostora, to jest, faktor razvoja funkcijskih odnosa i veza u njemu. U geografiji, to stanovište podržavaju i kasnije, pod uticajima Hegerštanda (Hägerstrand, T.) i Ajzara (Isard, W.) razvijeni pravci „time geography“ $i$,time- space geography“ (Tošić, D., 2012).

$\mathrm{Na}$ osnovama pomenutih modela i izvedenih kriterijuma po njima formiraju se tabele sa kvantitativno-kvalitativnim indikatorima i karte migracija stanovništva, koje imaju veliku aplikativnost u lokalnom, regionalnom, nacionalnom i transnacionalnom prostornom planiranju regionalnog razvoja.

\section{MEĐUNARODNE MIGRACIJE - IZAZOVI ZA EU}

Međunarodne migracije menjaju svet i predstavljaju najvažniju determinantu globalizacije, a u prvom redu najrazvijenih država Evrope. Sve više se povećava obim migracija, njihova složenost i uticaj. Tradicionalni migracioni tokovi su dopunjeni novim tipovima prostorne mobilnosti usled promena geografskih, demografskih, ekonomskih, političkih i društvenih uslova u državama porekla i destinacije. Na kraju dvadesetog i početku dvadeset prvog veka, vidljivo je jačanje ukupne prostorne pokretljivosti stanovništva u lokalnim, regionalnim, nacionalnim i međunarodnim razmerama. Pored toga, došlo je i do promena u obimu i pravcima migracija.

Imigracioni procesi u Evropi prošli su kroz nekoliko značajnih i prepoznatljivih faza, koje su bile uslovljene stepenom regionalnog razvoja $u$ određenom periodu, promenama u geografskim pokazateljima migracija, promenama u tipovima migracija i karakteristikama lica koja migriraju (Penninx, 2014). Sa ovim u vezi, izdvajaju se četiri perioda karakteristična za prostornu pokretljivost stanovništva na Evropskom kontinentu. Prvi period od 1950-1974. godine, koji je označen kao period migracije gostujućih radnika i dekolonizacije. Drugi period, koji je trajao od 1974. do 1989. godine, predstavlja period naftne krize i uvođenja kontrole migracionih tokova. Tokom trećeg perioda od 1990-2004. godine intenziviraju se migracije unutar Evrope od istoka ka zapadu, 
uz izdvajanje novih država imigracije, a povećava se i broj tražilaca azila, te sve to upućuje na kreiranje novih politika prema migrantima. Zadnji, odnosno četvrti period počinje 2004. godine i traje do danas, a odlikuje se intenzivnom mobilnosti unutar Evropske unije, diversifikacijom tipova migracija i država porekla migranata, kao i velikim povećanjem broja tražilaca azila. $S$ tim u vezi izdvojene su različite migracione politike koje se odnose pre svega na procese prihvatanja ili ne prihvatanja migranata, kao i na procese integracije na određenoj teritoriji. Tako se izdvajaju severozapadni, južnoevropski, centralno i istočno evropski migracioni $i$ integracioni režim, kao i režim Evropske unije koji podrazumeva slobodu kretanja unutar njenih granica.

Kao što smo napred naveli, Evropa se danas suočava sa najvećom migracionom krizom od Drugog svetskog rata. Tokovi migranata sa Bliskog Istoka, Afrike i iz Južne Azije predstavljaju svojevrstan izazov, koji zahteva brzu reakciju i donošenje odluka u cilju kreiranja svrsishodnih politika upravljanja migracionom krizom. Do kraja 2014. godine Turska je registrovala više od 1,5 miliona izbeglica. Pored toga, u toku 2014. godine primljeno je 79.000 ne sirijskih tražilaca azila u istom periodu. Ruska Federacija je registrovala više od 274.000 zahteva za status izbeglice i privremeni azil, prvenstveno iz Ukrajine (98,7\%), sa manjim brojem iz Avganistana i Sirije. Ukupno 28 država članica EU zajedno je registrovalo preko 500.450 zahteva za azil između juna i decembra 2014. godine. Pet zemalja primilo je gotovo $70 \%$ svih prijava- Nemačka (156.013), Švedska (73.945), Italija (51.262) i Mađarska (27.291). Najveći broj zahteva za azil (109.439) podnešen je od strane državljana Sirije, koji su činili $25 \%$ novih prijava u EU. lako je manji broj prijava za azil tražen u Jugoistočnoj Evropi, njihov broj je porastao sa 10.000 u 2013. godini na preko 20.000 u 2014. godini. Najveći broj je registrovan upravo u Srbiji. Tako su, 2015-ta i 2016-ta godina označene kao godine izazova i velikih odluka, usled ogromnog priliva migranata u države članice Evropske unije, što je uzrokovalo njihovu ključnu ulogu u regulisanju migracionih tokova. Zbog toga je neophodno koristiti ispravnu terminologiju vezanu za pojedine tipove migracija, u cilju odgovarajućeg rešavanja statusa ovih lica u državama odredišta. To se u prvom redu odnosi na termine miks migracije, ekonomski migranti, izbeglice, iregularni migranti itd. Danas, je po dostupnim statističkim podacima, svaki sedmi stanovnik sveta promenio mesto svog prebivališta. Shodno tome postavlja se pitanje da li su migracije usmerene od istoka ka zapadu, sa juga ka severu, iz siromašnih ka bogatim državama, ili/i koje su trenutno vodeće migracione, a koje emigracione države. Sve to implicira intenziviranje pokušaja država EU da regulišu migracije na svojoj teritoriji preko kreiranja efikasnih politika prostorne mobilnosti i intenziviranja bilateralnih, regionalnih i međunarodnih pregovora u ovom domenu (Šantić, \& Spasovski, 2016).

Formiranje Šengenske zone, koja predstavlja prvu zajedničku odnosno internacionalnu granicu u istoriji Evrope, uslovilo je promenu političke geografije migracija sa značajnim implikacijama sagledavanim iz raznih perspektiva, a koje su uticale na upravljanje migracijama, kako u državama članicama Evropske unije, tako i u trećim zemljama. Danas se Evropa nalazi između šanse za integraciju i izazova ponovnog uspostavljanja granica, a što je još kompleksnije pitanje, podizanja barijera na njima. Kao tri karakteristična faktora migracione politike EU navode se: Šengenska zona, čije kreiranje predstavlja najvažniji rezultat projekta evropske integracije, čiji je finalni doprinos realizacija slobode kretanja, bezbednost i pravda; Fronteks, koja predstavlja organizaciju EU zaduženu za upravljanje spoljnim granicama unije; Dablinska regulativa, koja predstavlja jedinstvenu politiku EU prema pitanjima azila (Giordano, 2016). Ali, sa masovnim migracionim tokovima od 2015. godine, došlo je do suspendovanja Šengenskog sporazuma i Dablinske regulative i/li njihove modifikacije, a umesto Fronteksa uspostavljena je nova agencija za monitoring granica. To stvara obavezu zemljama na spoljnim granicama Šengenske zone, ali i državama koje nisu članice EU da nadgledaju granice, da upravljaju iregularnim migracionim tokovima, a pre svega tokovima izbeglog stanovništva, iako su često nepripremljene da se bave imigracionim fenomenima. Nedostatak jedinstvene migracione politike Evropske unije, egocentrični pristup pojedinih ne-Mediteranskih država i ponovno pojavljivanje zidova na granicama karakteriše savremenu Evropu. Ipak, izazovi migracionih procesa i pojava nove vrste terorizma u Evropi 
predstavljaju značajnu mogućnost da se ojača zajednička evropska teritorija. Zajednički evropski azilni sistem (CEAS), ima potencijal da značajno unapredi regionalni i međunarodni okvir zaštite. lako je ostvaren napredak, njegova implementacija i konkretne mere će biti potrebne kako bi se CEAS pretvorio u pravi sistem zajedničke odgovornosti i solidarnosti, zasnovan na poverenju između država članica EU. Nakon poziva Agencije za izbeglice organizacije ujedinjenih nacija (United Nations High Commissioner for Refugees - UNHCR) da privremeno zaustavi transfer u Bugarsku u skladu sa dablinskom regulativom 2014 . godine, Bugarska je delovala kako bi rešila određene sistemske regulatorne nedostatke prilikom prijema azilanata uz podršku UNHCR-a, Zajedničkog evropskog azilnog sistema (CEAS) i Evropske komisije (Overview of UNHCR"s operations in Europe, 2015).

Tokom 2015. u Evropu je ušlo rekordnih 1,25 miliona Sirijaca, Iračana, Avganistanaca i drugih migranata. Priliv migranata izazvao je oštre reakcije u nekim članicama Evropske unije, uključujući Austriju, gde je anti migraciona Slobodarska partija gotovo pobedila na predsedničkim izborima u maju prošle godine, kao i Mađarsku, koja je podigla žičanu ogradu na granici sa Srbijom i okarakterisala nelegalni prelazak granice kao krivično delo koje se kažnjava zatvorom. Većina Austrijanaca smatra da njihova zemlja nazaduje i uzrok tome vide u prihvatanju izbeglica. Slično mišljenje počinje da vlada i u Nemačkoj, gde se smatra da „propuštanje“ izbeglica ugrožava Šengen. U Austriji i Nemačkoj većina ocenjuje da imigracija sa Bliskog Istoka i Afrike donosi više negativnih stvari nego prednosti. $U$ Austriji preovlađuje to mišljenje sa 67 prema $9 \%$, a u Nemačkoj je to 57 prema $12 \%$. Na pitanje da li masovna imigracija značajno utiče na sopstveno blagostanje, u Austriji je polovina ispitanika odgovorila potvrdno, a u Nemačkoj samo jedna trećina ispitanih stanovnika. Ukupno gledano, stav prema strancima u obe zemlje obeležen je skepsom i odbijanjem, pri čemu u Austriji ima većih predrasuda. Tako $48 \%$ ispitanih Austrijanaca i $32 \%$ Nemaca smatra da imigracija ljudi sa Bliskog Istoka i severa Afrike sve više potiskuje dosadašnji način života, te da su domicilnom stanovništvu radna mesta ugrožena zbog stranaca. $\mathrm{Na}$
Konferenciji u Beču održanoj 24. februara 2016. godine, predstavnici ministarstava unutrašnjih poslova Austrije, Hrvatske, Slovenije i zapadnobalkanskih zemalja, još jednom su potvrdili dominantnost pitanja bezbednosti, posebno zaštite granica kroz usvajanje Deklaracije o zajedničkom upravljanju granicama (fondacija Fridrih Ebert, 2016).

Na političkoj sceni pojavljuje se slično mišljenje, pa je Evropska komisija predstavila dva predloga za temeljne izmene sistema traženja azila u EU, takozvanih Dablinskih propisa. Prema važećim pravilima, koja su dovedena u pitanje velikim prilivom migranata tokom 2015. i 2016. godine, azil se mora zatražiti u prvoj zemlji članici u koju kroči tražilac azila (uglavnom Grčka i Italija). Međutim, migranti su prolazili kroz brojne bezbedne zemlje EU i preko Balkana bez pokretanja procedure, da bi na kraju iz ekonomskih razloga podneli zahtev za dobijanje azila u Austriji, Nemačkoj ili Švedskoj, a pri tome institucije EU nisu uspele da uspostave efikasan sistem podele odgovornosti među članicama.

$\mathrm{Na}$ nivou Evropske unije najrelevantniji instrumenti su Direktiva 2011/36/EU od 5. aprila 2011. godine o prevenciji i borbi protiv trgovine ljudima i zaštiti žrtava trgovine i Direktiva o sankcijama protiv poslodavaca državljana trećih zemalja koji ilegalno borave u zemlji. Direktiva EU o trgovini ljudima iz 2011. godine određuje trgovinu ljudima kao teško kršenje ljudskih prava. Posebnu pažnju usmerava na identifikovanje, pomoć i zaštitu žrtava, uključujući i decu žrtve, kompenzaciju žrtvama i njihovo izuzimanje od tužbe.

Pored Direktive o trgovini ljudima, relevantan je i veliki broj drugih, već postojećih direktiva Evropske unije, ili onih koje su u pripremi: Direktiva o sankcijama protiv poslodavaca državljana trećih zemalja koji ilegalno borave u zemlji, Direktiva EU o privremenoj boravišnoj dozvoli, Direktiva EU o borbi protiv seksualne zloupotrebe, seksualne eksploatacije dece i dečije pornografije, Direktiva o minimalnim standardima za prava, podršku i zaštitu žrtava krivičnog dela. Cilj Direktive EU o kompenzaciji za žrtve krivičnih dela je da obezbedi da svaka država članica poseduje važeći nacionalni plan kojim se garantuje pravična i prikladna kompenzacija žrtvama krivičnih dela, a koji se na žrtve 
primenjuje bez obzira na to $u$ kojoj su zemlji Evropske unije postale žrtve krivičnog dela. Samo u nekoliko država Evrope, među kojima su Finska, Italija, Holandija, Portugal, Španija, postoji mogućnost odobravanja azila žrtvama trgovine ljudima i u slučajevima da ne sarađuju sa državnim organima $u$ procesuiranju trgovaca ljudima.

Uloga Srbije kao države suseda, na spoljnim granicama EU i sa dugom tradicijom iseljavanja, postaje sve značajnija. Srbija se nalazi na Balkanskoj migracionoj ruti i suočava se sa brojnim izazovima u regulisanju migracionih tokova: usklađivanju pravnog, administrativnog i institucionalnog zakonskog okvira sa Evropskom unijom, kao i potrebe ispunjavanja uslova za pristupanje ovoj zajednici kroz regulisanje statusa izbeglica, interno raseljenih lica i povratnika prema Zakonu o readmisiji i uspostavljanju sistema azila. Takozvana "Balkanska ruta“ je praktično zatvorena za prolazak migranata, iako posle razgovora u Briselu o izbegličkoj krizi članice EU nisu želele da zvanično proglase zatvaranje tog puta kojim je prošle godine prošlo više od 850 hiljada izbeglica i migranata. Istovremeno, Slovenija je nakon načelnog dogovora EU i Turske odlučila da omogući ulazak migrantima samo u skladu sa šengenskim propisima i da od 9. marta 2017. u ponoć propušta samo migrante sa dokumentima koji su potrebni za ulazak u zemlje članice šengenskog sistema. To praktično znači da osobama bez pasoša i viza neće biti omogućen ulazak, osim ako ne postoje humanitarno razlozi. "Neregularni protok migranata zapadnobalkanskom rutom sada je završen", rekao je 8. Marta 2017. Godine, premijer Slovenija Miro Cerar. Ministarstvo unutrašnjih poslova Srbije saopštilo je 8. marta 2017. godine, da je obaveštenje o merama Slovenije dobilo od Hrvatske i da novi režim "praktično zatvara balkansku rutu". MUP (Ministarstvo unutrašnjih poslova) je dodao da Srbija ne može da postane sabirni centar za izbeglice zbog čega će sve mere usaglašavati sa EU i recipročno ih primenjivati na južnim i istočnim granicama, prema Makedoniji i Bugarskoj. Prema podacima UNHCR-a, u Srbiji je od 9. marta 2017 godine u ponoći kada su zatvorene granice za prolaz migranata na takozvanoj balkanskoj ruti ostalo oko 2.000 izbeglica sa Bliskog istoka, smeštenih u četiri prihvatna centra na jugu i severu zemlje.
Makedonija je, takođe, saopštila da će prihvat i tranzit migranata uskladiti sa koracima koje preduzimaju druge zemlje na balkanskoj ruti. Hrvatski ministar unutrašnjih poslova Vlaho Orepić potvrdio je 8. marta uveče da i Hrvatska počinje da primenjuje nova pravila ulaska izbeglica koja podrazumevaju da samo oni $s$ valjanim putnim ispravama mogu da pređu granicu.

Takođe, priliv će u velikoj meri zavisiti od toga kako će se rešiti krize koje su uzrok migracijaodnosno da li će mirovni razgovori o Siriji biti uspešni, kao i napori za stabilizovanje situacije u Libiji i teške političke i ekonomske situacije u nekim zemljama Afrike i Bliskog Istoka.

\section{UMESTO ZAKLJUČKA}

Danas, živimo u vremenu kulminacije velikih ekoloških, socijalnih, ekonomskih i drugih kriza, sa vidljivim efektima na iznuđenu prostornu pokretljivost ljudi (najveća izbeglička i migraciona kretanja stanovništva u poslednjih pedeset godina). Ljudi u pokretu, sa problemima i potrebama različitih vrsta, a posebno izbeglice i migranti, su njihov indikator i nerazdvojna komponenta. lako pojedinci i društvene zajednice mogu da razviju znatan kapacitet adaptacije, tolerancije i izdržljivosti na nepovoljne uticaje kako prirodnog, tako i društvenog okruženja, kritični pragovi uvek postoje. Negativne promene, ukupnih ili pojedinačnih uslova, iznad nivoa kritičnih pragova, po pravilu imaju za posledicu nelinearne efekte u zoni svog uticaja, na pojavu i obim izbeglica i migracija. Tako se izbeglice i migranti, kao kompleksne, dinamične i višeznačne socijalne kategorije, bez obzira na genezu njihove pojave, mogu smatrati pokazateljima uspona i padova, kao i sveukupne vertikale problema egzistencije ljudi (Jovanović Popović, 2015).

Dakle, možemo zaključiti da su zemlje Severne, Zapadne i Južne Evrope postale zemlje imigracije, iako neke od njih odbijaju da prepoznaju dugoročnu potrebu za migrantima, što je posledica decenijskog smanjenja radno sposobnog i fertilnog stanovništva, kao i starenja u ovim državama. Međutim, kada se ove države budu suočile sa demografskim deficitom $i$ zahtevima za određenim tipom radne snage, uslediće politički pritisak koji će dovesti do 
kreiranja otvorenijih i proaktivnih politika prema migrantima (Penninx, 2016).

Na kraju uviđamo da su migracione teme među najaktuelnijim pitanjima današnjice $i$ te da je migraciona problematika u osnovi procesa razvoja u savremenom svetu. Migracije treba posmatrati sa interdisciplinarnog stanovišta i samo u tom slučaju možemo donositi smislene odluke o ovoj problematici i kreirati svrsishodne politike za upravljanje ovim fenomenom. Migracije $u$ današnjem vremenu predstavljaju planetarni fenomen, jednako važan na globalnom i na lokalnom nivou. Smatramo da bi bilo svrsishodno da se dosadašnja naučna istraživanja migracija $u$ Srbiji, Evropi i svetu, detaljnije predstave i povežu i da samo povezana naučna istraživanja migracija mogu adekvatno doprineti da ovaj fenomen bude detaljnije posmatran i proučen.

\section{CITIRANI RADOVI}

Albrecht, G. (1972). Soziologie der geografischen Mobilitat: Zugleich ein Beitrag zur Soziologie des sazialen Wandels. Stuttgart: FerdinandEnke Verlag. .

Bolte, K. M. (1969). Vertikale Mobilität. Stuttgard: Handbuch der empirischen Sozialforschung.

Commissioner's, E. C. (2015). Overview of UNHCR,s operations in Europe. UNHCR. Retrieved 725 , 2017, from http://www.unhcr.org/excom/standcom/54fd6fd49/overview-unhcrs-operationseurope.html?query=number\%20of\%20refuges\%20in\%20uropa

Giordano, A. (2016). The New Political Geography of Migration in Europe: Between External Borders and Internal Freedom. Belgrade: Serbian Geographical Society.

Jonjić, P. (1984). Teorijski aspekti proučavanja migracije: kritički pregled literature" u Teorije i modeli istraživanja migracija. Zagreb: Centar za istraživanje migracija i narodnosti.

Jovanović Popović, D; Milinčić, M; (2015). Ekološke izbeglice-koncept statusna pitanja i izazovi. Beograd: Srpsko geografsko društvo, 81-130.

Klingbeil, D. (1969). Zur Sozialgeographicsher Theorie und entfassung des Taglichen Berrspandelns. Geographische Zeitschtrift.

Klingbeil, D. (1980). Zeit als Process und Ressource in der sozialwissenschaftlichen Humangeographie. Wiesbaden: Geographische Zeitschtrift 68.

Penninx, R. (2014). Regional Economic Integration and Migration: Lessons from the Case of Europe. Springer International Publishing.

Penninx, R. (2016). International Migration and Related Policies in Europe. Belgrade: Serbian Geographical Society.

Petersen, W. (1958). General Tipology of Migration. American sociological Review.

Predojević Despić, J. (2009). Migrantske mreže - nezaobilazna perspektiva u proučavanju savremenih međunarodnih migracija. Beograd: Sociološki pregled,43(2), 209-229.

Šantić, D., Spasovski, M. (2016). Contemporary World Migration - Towards New Terminology, Patterns and Policies. Beograd: Glasnik Srpskog geografskog društva, 96(2), 5-17

Tošić, D; Krunić, N; \& Petrić, J. (2007). Dnevni urbani sistemi - prostorni izraz dnevne migracije stanovništva. Demografija, IV. Beograd: Geografski fakultet-Institut za demografiju.

Tošić, D. (2012). Principi regionalizacije, Beograd. Beograd: Geografski fakultet.

Zelinsky, W. (1971). The hypothesis of the mobility transition. Geographical Review.

Datum prve prijave:

Datum prijema korigovanog članka:

Datum prihvatanja članka:
15.03.2018.

20.07.2018.

05.09.2018. 
Kako citirati ovaj rad? / How to cite this article?

Style - APA Sixth Edition:

Todorović, V., Lutovac, M. D., \& Radulović, J. (2018, 10 15). Statusna pitanja ekonomskih izbeglica i izazovi za Evropsku uniju. (Z. Čekerevac, Ur.) FBIM Transactions, 6(2), 180-187. doi:10.12709/fbim.06.06.02.18

Style - Chicago Sixteenth Edition:

Todorović, Vladimir, Miloš D. Lutovac, i Jovana Radulović. 2018. „Statusna pitanja ekonomskih izbeglica i izazovi za Evropsku uniju." Urednik Zoran Čekerevac. FBIM Transactions (MESTE) 6 (2): 180187. doi:10.12709/fbim.06.06.02.18.

Style - GOST Name Sort:

Todorović Vladimir, Lutovac Miloš D. i Radulović Jovana Statusna pitanja ekonomskih izbeglica i izazovi za Evropsku uniju [Časopis] // FBIM Transactions / ur. Čekerevac Zoran. - Beograd : MESTE, 1510 2018. - 2 : T. 6. - str. 180-187.

Style - Harvard Anglia:

Todorović, V., Lutovac, M. D. \& Radulović, J., 2018. Statusna pitanja ekonomskih izbeglica i izazovi za Evropsku uniju. FBIM Transactions, 15 10, 6(2), pp. 180-187.

Style - ISO 690 Numerical Reference:

Statusna pitanja ekonomskih izbeglica i izazovi za Evropsku uniju. Todorović, Vladimir, Lutovac, Miloš D. i Radulović, Jovana. [ur.] Zoran Čekerevac. 2, Beograd : MESTE, 1510 2018, FBIM Transactions, T. 6, str. 180-187. 